\title{
Synthesis of Nanocrystalline Oxide Ceramic Materials:a Carbon Nanoreactor Concept
}

\author{
Alexander M. Volodin, Alexander F. Bedilo, Aleksey A. Vedyagin* and Vladimir 0. Stoyanovskii \\ Boreskov Institute of Catalysis SB RAS, Novosibirsk, Russia
}

Submitted: December 06, 2017; Published: December 15, 2017

*Corresponding author: Aleksey A Vedyagin, Boreskov Institute of Catalysis SB RAS, Novosibirsk, Russia, Email: vedyagin@catalysis.ru

\begin{abstract}
Carbon-coated nanocrystalline oxides $\mathrm{TiO}_{2} @ \mathrm{C}, \mathrm{Al}_{2} \mathrm{O}_{3} @ \mathrm{C}$ and calcium aluminate $\mathrm{C} 12 \mathrm{~A} 7 @ \mathrm{C}$ were synthesized, and the effect of carbon coating on their thermal stability and reactivity was studied. It was found that the carbon coating prevents sintering of the titanium nanoparticles and contributes to stabilization of their size. Thus, the particle size of anatase can be stabilized at level of 10-12 $\mathrm{nm}$ even after heat treatment at $750^{\circ} \mathrm{C}$. Deposition of the carbon coating on $\gamma-\mathrm{Al}_{2} \mathrm{O}_{3}$ prevents growth of the alumina nanoparticles and substantially improves their thermal stability. Complete $\mathrm{Al}_{2} \mathrm{O}_{3}$ conversion to corundum occurs after heat treatment at $1250^{\circ} \mathrm{C}$, whereas practically no corundum is formed under similar conditions for $\mathrm{Al}_{2} \mathrm{O}_{3} @ \mathrm{C}$. Dispersed calcium aluminate $\mathrm{C} 12 \mathrm{~A} 7$ particles resistant to sintering at high-temperature were synthesized inside the carbon shell. Meanwhile, intense sintering at high temperatures was observed for the samples without the carbon coating. The carbon shell prevents sintering and makes it possible to synthesize samples in a disperse state even at $1450^{\circ} \mathrm{C}$. According to TEM data, characteristic sizes of C12A7 particles inside the carbon coating range from $100 \mathrm{~nm}$ to several microns. So, the core-shell approach can be used to stabilize the size of the oxide core nanoparticles up to temperatures when their reaction with the coating material occurs. In the case of the carbon shell, this is the temperature when the carbothermal reduction of the oxide core takes place.
\end{abstract}

Keywords: Nanocrystalline oxides; Carbon nanoreactor; Titanium; Alumina; Calcium aluminate; Phase transformation

\section{Introduction}

Size effects play an important role in various chemical and phase transformations of oxides. For example, nanocrystalline mesoporous oxides often have high reactivity in many chemical reactions making them efficient catalysts [1,2] and destructive sorbents [3-7] for neutralization of various toxic compounds. However, products resulting from their solidstate reactions are usually non-nanocrystalline. Solid-state reactions of nanocrystalline oxides are typically accompanied by particle sintering and formation of a new phase in the form of significantly enlarged particles. The same is true for the phase transformations taking place with the temperature increase and leading to the growth of the precursor nanoparticles.

Unique properties of calcium aluminate with $12 \mathrm{CaO} \cdot 7 \mathrm{Al}_{2} \mathrm{O}_{3}$ stoichiometric often labeled as $\mathrm{C} 12 \mathrm{~A} 7$ were discovered and investigated in numerous studies by Hosono et. al [8-10]. These materials contain a stable cation framework $\left[\mathrm{Ca}_{24} \mathrm{Al}_{28} \mathrm{O}_{64}\right]^{4+}$ and changeable anion sub lattice $4 \mathrm{X}^{-}$. Chemical and physical properties of these materials can be varied in a wide range by varying the $\mathrm{X}^{-}$anions, where $\mathrm{X}^{-}$can be $\mathrm{H}^{-}, \mathrm{O}^{-}, \mathrm{O}_{2}^{-}, \mathrm{O}^{2-}, \mathrm{OH}^{-}, \mathrm{Cl}^{-}$, $\mathrm{F}^{-}, \mathrm{e}^{-}$. Recently we have demonstrated that the carbon coating deposited on the surface of oxide nanoparticles can act as a nanoreactor shell. The schematic imagination of the carbon nanoreactor concept is shown in Figure 1. The carbon coating prevents sintering of nanoparticles inside the shell during at high temperatures and stabilizes their size. Moreover, such coating can be penetrable for reactant molecules from both the gas or liquid phases [7,11-13] making it possible to initiate various catalytic or solid-state reactions inside the nanoreactor. This study is devoted to investigation of phase and chemical transformations of carbon-coated nanocrystalline oxides $\mathrm{TiO}_{2} @ \mathrm{C}, \mathrm{Al}_{2} \mathrm{O}_{3} @ \mathrm{C}$ and calcium aluminateC12A7@C.

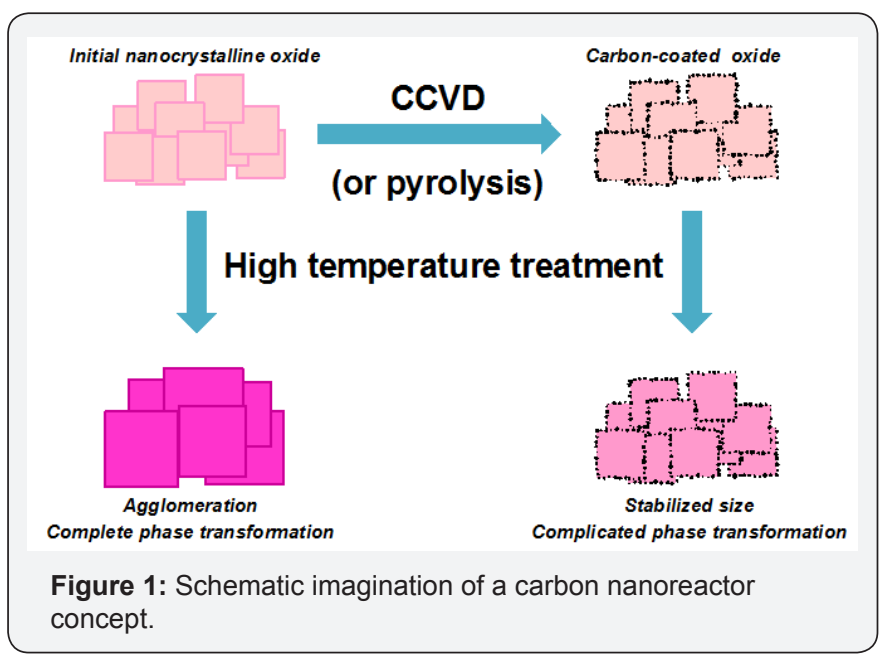

\section{Experimental}

Nanocrystalline $\mathrm{TiO}_{2}$ hereinafter abbreviated as $\mathrm{NA}^{-\mathrm{TiO}_{2}}$ was obtained by a sol-gel method using titanium n-but oxide as a 
precursor and a mixture of ethanol and toluene with a volume ratio of $1: 3$ as a solvent. Nitric acid was added to the solution in a ratio of $0.1 \mathrm{~mol}$ per $1 \mathrm{~mol}$ of Ti. Then it was hydrolyzed by a stoichiometric amount of water at a room temperature. The resulting white gel was dried in an oven at $110^{\circ} \mathrm{C}$ for 1 day. The specific surface area SSA of the dried sample with amorphous structure was $540 \mathrm{~m}^{2} / \mathrm{g}$. After calcination in air at $500{ }^{\circ} \mathrm{C}$, the SSA of the sample was about $90 \mathrm{~m}^{2} /$ g. $\gamma-\mathrm{Al}_{2} \mathrm{O}_{3}$ sample used as a precursor for synthesis of all other samples was obtained by calcination of Condea "Pural SB-1" pseudobohemite sample in air at $720^{\circ} \mathrm{C}$ for $6 \mathrm{~h}$ with prior temperature increase to $720^{\circ} \mathrm{C}$ at a ramping rate of $1.5^{\circ} \mathrm{C} / \mathrm{min}$. The SSA of this sample was about $210 \mathrm{~m}^{2} / \mathrm{g}$. In order to prepare the carbon shell, the $\gamma-\mathrm{Al}_{2} \mathrm{O}_{3}$ and $\mathrm{TiO}_{2}$ precursors were mixed with polyvinyl alcohol PVA in a 7:3 weight ratio. Then, the obtained mixture was heated in a quartz reactor in an argon flow to $750^{\circ} \mathrm{C}$ with $1.5^{\circ} \mathrm{C} / \mathrm{min}$ heating rate and kept at this temperature for $6 \mathrm{~h}$ for $\gamma-\mathrm{Al}_{2} \mathrm{O}_{3}$ and $3 \mathrm{~h}$ for $\mathrm{TiO}_{2}$. For treatment at higher temperatures, the obtained sample was placed into a graphite crucible that was installed into acorundum tube assembled inside a tubular Star bar TSR heater. Then the sample was heated in an argon flow with the heating rate of 3 ${ }^{\circ} \mathrm{C} / \mathrm{min}$ up to the desired temperature varied from 960 to $1450^{\circ} \mathrm{C}$ and kept at this temperature for $6 \mathrm{~h}$. A mixture of aluminum and calcium hydroxides of required stoichiometric was used as a precursor for C12A7 synthesis. The mixture was thoroughly stirred in distilled water for $10 \mathrm{~h}$, filtered, dried at $110^{\circ} \mathrm{C}$ and calcined at $550^{\circ} \mathrm{C}$ for $6 \mathrm{~h}$.

The obtained C12A7-550 sample was used as a precursor for further synthesis. To prepare the carbon-coated samples, C12A7-550 powder was mixed with polyvinyl alcohol in a 7:3ratio with subsequent calcination in an argon atmosphereat desired temperature. High-temperature treatment of the samples was carried out in a special corundum ampoule. The ampoule was located inside the high-temperature tubular furnace manufactured using Starbar ${ }^{\circledR}$ carbide-silicon heating element with the working temperature interval up to $1500^{\circ} \mathrm{C}$. The temperature ramping rate was $4^{\circ} \mathrm{C} / \mathrm{min}$. Each sample was kept at the final temperature for 6h. X-ray diffraction (XRD) patterns of the samples were recorded using a Brucker D8 diffractometer. Electron paramagnetic resonance (EPR) studies were performed using an ERS-221 EPR spectrometer. EPR spectra were acquired at room temperature. HRTEM images were obtained using a JEM-2010 electron microscope (JEOL Japan) with a lattice-fringe resolution of $0.14 \mathrm{~nm}$ at accelerating voltage of $200 \mathrm{kV}$. The samples for HRTEM were prepared on a perforated carbon film mounted on a copper grid. The values of SSA calculated by the BET method were determined from the data obtained by low-temperature argon adsorption using an ASAP-2400 instrument. Raman spectra were recorded using a LabRAM HR800 spectrometer from HORIBA Jobin Yvon with a Symphony CCD detector. For spectral excitation the $488 \mathrm{~nm}$ line of an $\mathrm{Ar}^{+}$laser (35LAP431 from Melles Griot, USA) was used.

\section{Results and Discussion}

\section{Carbon-coated nanocrystalline $\mathrm{TiO}_{2}$}

It was found that the carbon coating prevents the sintering of the titania nanoparticles and contributes to the stabilization of their size. In such materials, the particle size of anatase can be stabilized at level of $10-12 \mathrm{~nm}$ even after heat treatment at $750^{\circ} \mathrm{C}$. For instance, in the carbon-coated nanocrystalline $\mathrm{TiO}_{2}$ (NA$\mathrm{TiO}_{2} @ \mathrm{C}$ ), the rutile phase is practically absent whereas the same sample without carbon coating is completely converted to rutile after such procedure Figure 2. When the particle size is small (up to $15 \mathrm{~nm}$ ), the anatase phase is more thermodynamically stable. Therefore, the rutile phase formation occurs only when the size of the nanoparticles is above this critical value. While the carbon coating prevents the sintering of the nanoparticles at high temperatures, it helps to preserve their size and, consequently, stabilizes the anatase phase.

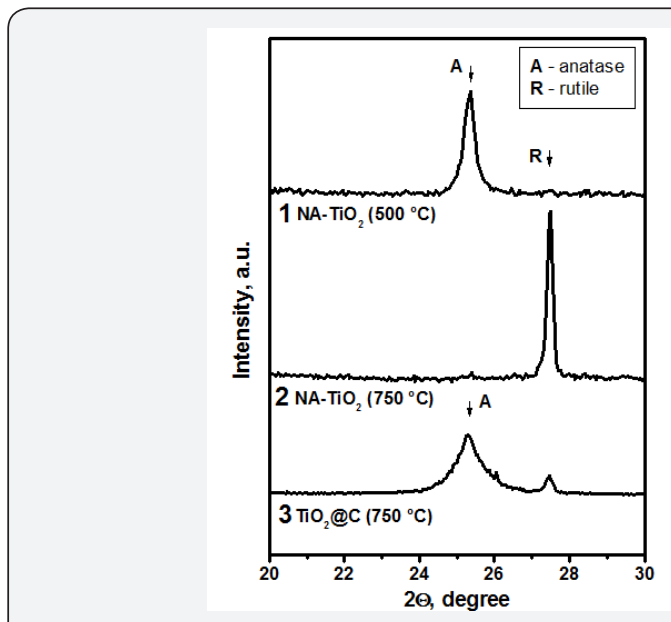

Figure 2: XRD patterns of nano crystalline $\mathrm{TiO}_{2}(1,2)$ and carboncoated $\mathrm{TiO}_{2} @ \mathrm{C}(3)$ after heating at $500{ }^{\circ} \mathrm{C}(1)$ and $750^{\circ} \mathrm{C}(2,3)$.

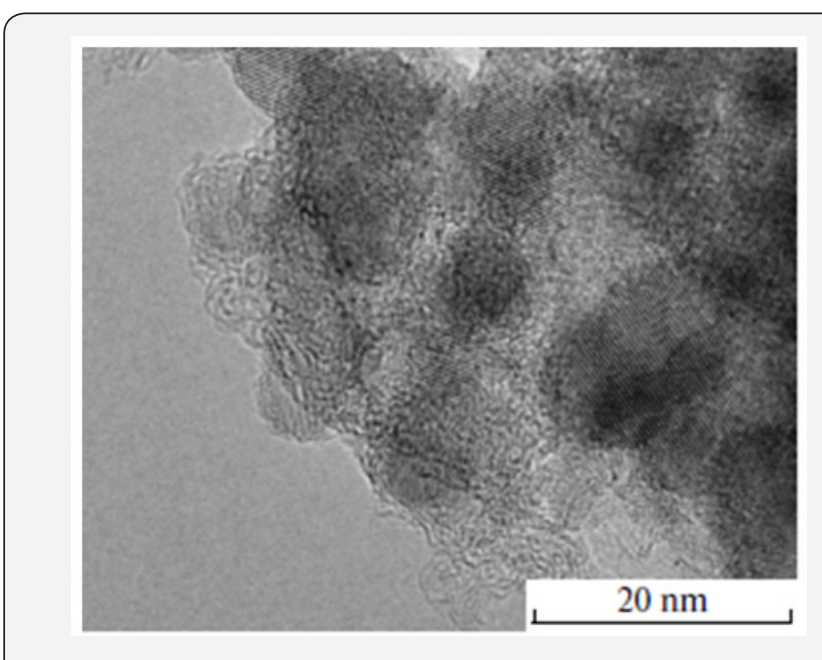

Figure 3: HRTEM image of the $\mathrm{NA}-\mathrm{TiO}_{2} @ \mathrm{C}$ after heating in argon atmosphere at $750^{\circ} \mathrm{C}$ for 3 hours. 


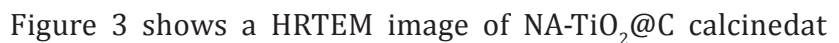
$750^{\circ} \mathrm{C}$. One can see that the size of carbon-coated $\mathrm{TiO}_{2}$ nanoparticles does not exceed $10-15 \mathrm{~nm}$. Meanwhile, the particles of the sample without the coating are $30-40 \mathrm{~nm}$ insize, and the phase is rutile. The data shown in Figures $2 \& 3$ clearly demonstrate that the carbon shell stabilizes the size andphase composition of the anatase nanoparticles within it. Figure 4 shows the effect of the carbon coating on the formation of acorundum phase resulting from the high temperature treatment of $\mathrm{Al}_{2} \mathrm{O}_{3}$ and $\mathrm{Al}_{2} \mathrm{O}_{3} @ \mathrm{C}$ samples. Complete conversion of the pure $\gamma-\mathrm{Al}_{2} \mathrm{O}_{3}$ precursor to $\alpha-\mathrm{Al}_{2} \mathrm{O}_{3}$ corundum was observed at $1180^{\circ} \mathrm{C}$ (Figure 3). Meanwhile, practically no corundum was formed in the case of carbon-coated material $\mathrm{Al}_{2} \mathrm{O}_{3} @ \mathrm{C}$. According to XRD data, only $\delta-\mathrm{Al}_{2} \mathrm{O}_{3}$ phase was observed.

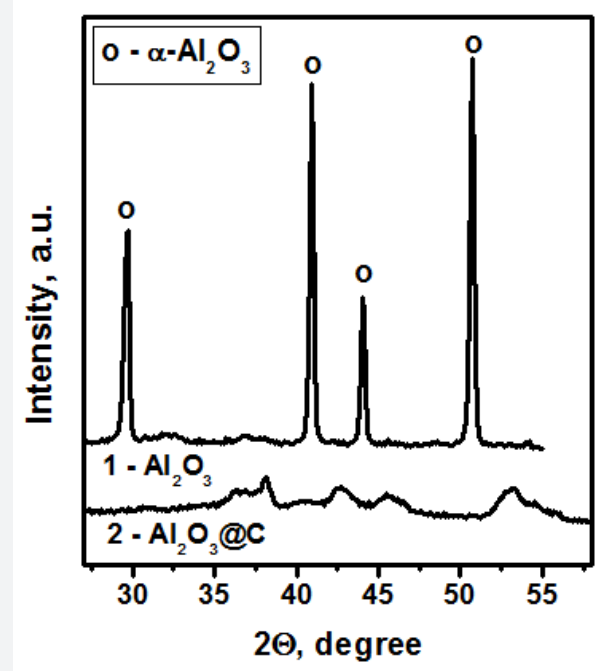

Figure 4: XRD patterns of $\mathrm{Al}_{2} \mathrm{O}_{3}(1)$ and $\mathrm{Al}_{2} \mathrm{O}_{3} @ \mathrm{C}(2)$ samples after calcinations at $1180^{\circ} \mathrm{C}$

The size of alumina crystallites was stabilized at $20-25 \mathrm{~nm}$. The $\mathrm{Al}_{2} \mathrm{O}_{3} @ \mathrm{C}$ sample could be transformed to corundum only after heat treatment at $1380^{\circ} \mathrm{C}$. Most likely, stabilization of the particle size by the carbon shell in $\mathrm{Al}_{2} \mathrm{O}_{3} @ \mathrm{C}$ samples is the main factor preventing their phase transformation to corundum. The growth of the nanoparticles size during the heat treatment naturally results in a loss of their SSA. Changes of the specific surface area of $\mathrm{Al}_{2} \mathrm{O}_{3}$ and $\mathrm{Al}_{2} \mathrm{O}_{3} @ \mathrm{C}$ samples after calcination at high temperatures are shown in Figure 5. Fast drop of the surface area at calcination temperatures around $1100^{\circ} \mathrm{C}$ is clearly observed for pure $\mathrm{Al}_{2} \mathrm{O}_{3}$. These are the temperatures when the corundum phase is formed. Meanwhile, for $\mathrm{Al}_{2} \mathrm{O}_{3} @ \mathrm{C}$ samples relatively high surface area is preserved until the calcination temperature of $1380^{\circ} \mathrm{C}$. Raman spectroscopy yields averaged information on the state of the carbon shell in $\mathrm{Al}_{2} \mathrm{O}_{3} @ \mathrm{C}$ samples. As it was recently reported [14], the Raman spectrum of $\mathrm{Al}_{2} \mathrm{O}_{3} @ \mathrm{C}$ sample calcined at $1230^{\circ} \mathrm{C}$ contains well-developed D at $1350 \mathrm{~cm}^{-1}, \mathrm{G}$ at $1587 \mathrm{~cm}^{-1}$, HWHM G-55 $\mathrm{cm}^{-1}, \mathrm{D}^{\prime}$ at $1615 \mathrm{~cm}^{-1}$ and $2 \mathrm{D}$ peaks near $2700 \mathrm{~cm}^{-1}$. These data indicate the formation of 1-3 monolayer of nanocrystalline graphite [15].

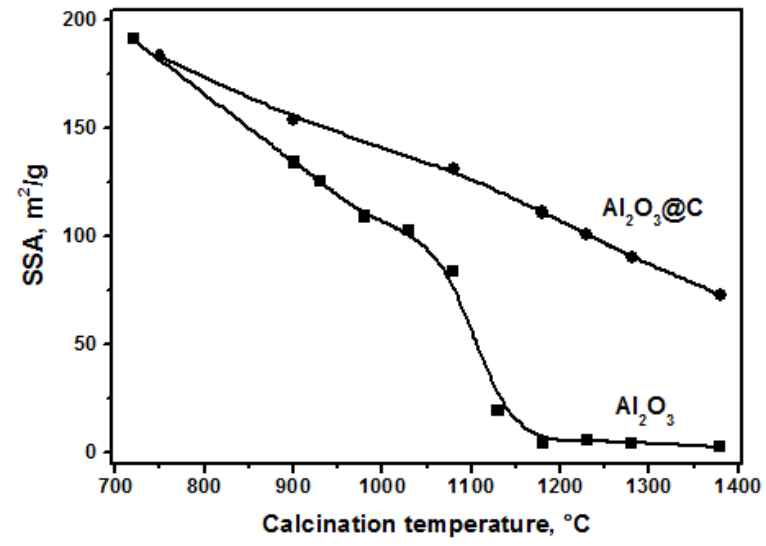

Figure 5: Effect of calcination temperature on $\mathrm{SSA}$ of $\mathrm{Al}_{2} \mathrm{O}_{3}$ and $\mathrm{Al}_{2} \mathrm{O}_{3} @ \mathrm{C}$

It should be noted that after removal of the carbon shell by calcination in air, the carbon-coated samples retained clearly visible grey color instead of white color of pure $\mathrm{Al}_{2} \mathrm{O}_{3}$ samples. This color appears only for $\mathrm{Al}_{2} \mathrm{O}_{3} @ \mathrm{C}$ samples calcined in anargon flow at relatively high temperature. The Raman spectrum of $\mathrm{Al}_{2} \mathrm{O}_{3} @ \mathrm{C}$ sample calcined in argon at $1230^{\circ} \mathrm{C}$ and additionally calcined in air at $700^{\circ} \mathrm{C}$ to burn off the carbon accessible to the gas phase is characterized by the lack of $2 \mathrm{D}$ peaks and substantially less intense D and G lines in comparison with the carbon-coated sample. This spectrum can be attributed to nano crystalline graphite particles encapsulated at places of contact between the $\mathrm{Al}_{2} \mathrm{O}_{3}$ nanoparticles, which account for the grey color of the samples.

\section{Carbon-coated calcium aluminate C12A7}

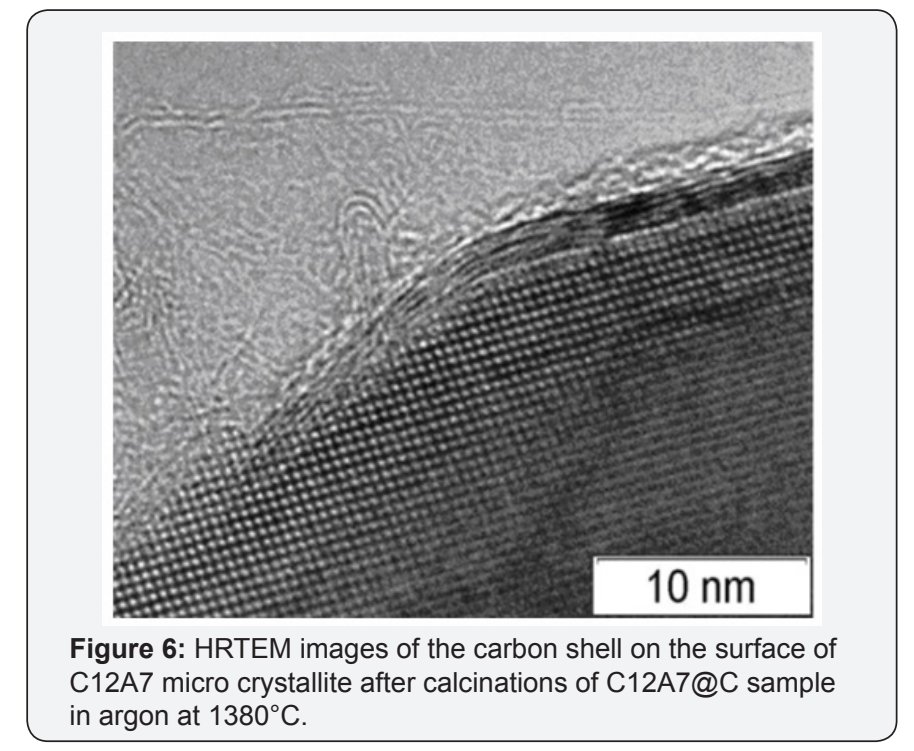

According to the XRD data, the formation of single-phase calcium aluminate $\mathrm{C} 12 \mathrm{~A} 7$ with mayenite structure occurs starting from $550{ }^{\circ} \mathrm{C}$. This structure is maintained for the samples subjected to treatment in argon at $1450{ }^{\circ} \mathrm{C}$. Intensive 
sintering at high temperatures was observed for samples without the carbon coating. The carbon shell prevents sintering, thus allowing synthesizing the samples in a disperse state even at $1450^{\circ} \mathrm{C}$. According to the TEM data, typical dimensions of C12A7 particles inside the carbon shell range from $100 \mathrm{~nm}$ to several microns. The carbon shell can have either a disordered structure or dense packing of graphenes into graphite layers (Figure 6). A disordered shell covers the graphite layer additionally shielding the C12A7crystal surface. Substitution of oxygen anions with $\mathrm{e}^{-}$in C12A7@Csystem, which is the initial stage of the electrodeC12A7: $\mathrm{e}^{-}$formation can be reliably detected by EPR due to appearance of a specific signal at $\mathrm{g}=1.994$ (Figure 7), which is well-known for bulk C12A7: $\mathrm{e}^{-}$materials $[8,9]$.

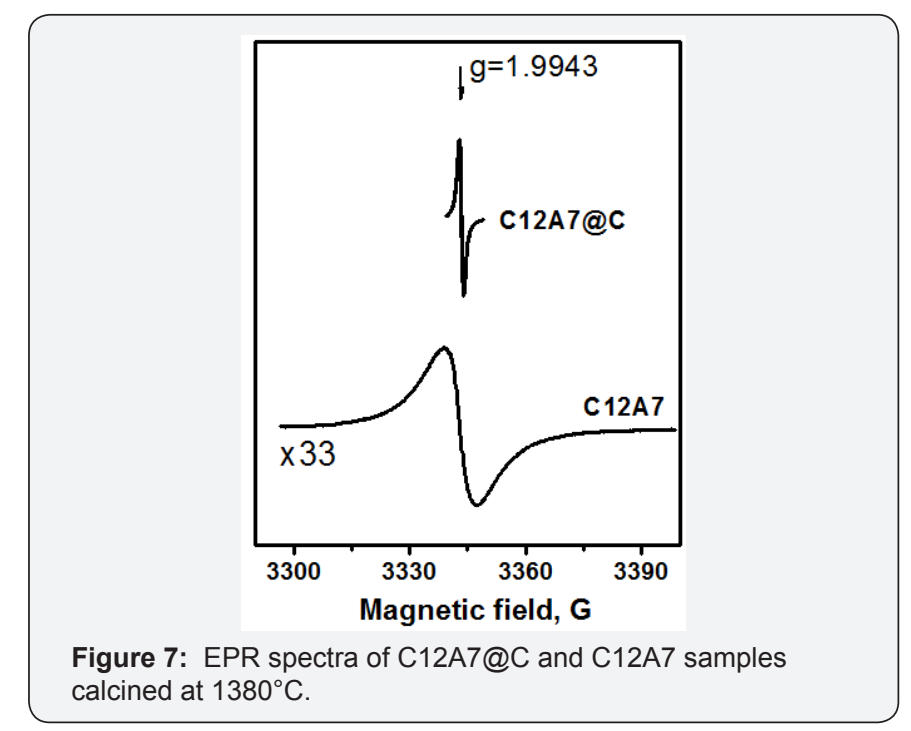

A similar spectrum with half-width of $8.7 \mathrm{G}$ was observed for $\mathrm{C} 12 \mathrm{~A} 7$ without the carbon coating calcined at $1380^{\circ} \mathrm{C}$. Meanwhile, the half-width of the EPR signal for C12A7@ Csamples was significantly lower and did not exceed $1 \mathrm{~g}$. The maximum concentration of paramagnetic sites in C12A7@C materials achieved in our experiments was $(2 \div 4) \times 10^{19} \mathrm{~g}^{-1}$, which is close to the literature data for samples synthesized from melts $[8,9]$. Meanwhile, our C12A7@C: $\mathrm{e}^{-}$materials possess relatively high surface areas. The SSA of C12A7@C sample was $24 \mathrm{~m}^{2}$ / gafter calcination at $1380^{\circ} \mathrm{C}$, where as $\mathrm{C} 12 \mathrm{~A} 7$ without carbon coating after heat treatment at the same temperature was as intered material with the SSA of $0.1 \mathrm{~m}^{2} / \mathrm{g}$. Thereby, the carbon coating prevents agglomeration of core nanoparticles at very high temperatures, and leads to the electrode formation inside the carbon shell. The use of the carbon nanoreactor approach allowed us to obtain the electrode with much higher dispersity if compared with the conventional method starting from the melt.

\section{Conclusion}

The results of the study indicate that preservation of a small particle size is a key factor hindering the phase transformations in the concerned $\mathrm{TiO}_{2} @ \mathrm{C}$ and $\mathrm{Al}_{2} \mathrm{O}_{3} @ \mathrm{C}$ systems. The presence of the carbon coating inhibits the sintering of the particles and makes it possible to synthesize new materials with the particle size similar to that of the initial particles of the oxide precursors. The suggested carbon nanoreactor concept can be used for synthesis of nanomaterials of different chemical nature with a wide range of potential use in modern technology. Carbon coating is just one of the ways to form a nanoreactor shell. It is obvious that such a shell will not always be inert and is completely unsuitable for high temperature synthesis in an oxygen environment. The core-shell method can be used to stabilize the size of the oxide core nanoparticles up to temperatures when their reaction with the coating material takes place. In the case of the carbon shell, this is the temperature when the carbothermal reduction of the oxide core begins. A search for other materials that can function as a nanoreactor shell and can make it possible to perform such synthesis in air is of great importance for many practical applications.

\section{Acknowledgement}

Financial support from Russian Science Foundation (project No. 16-13-10168) is acknowledged with gratitude.

\section{References}

1. Mishakov IV, Bedilo AF, Richards RM , Chesnokov VV, Volodin AM, et al. (2002) Nanocrystalline $\mathrm{MgO}$ as a dehydrohalogenation catalyst. J Catal 206(1): 40-48.

2. Wang J, Uma S, Klabunde KJ (2004) Visible light photocatalytic activities of transition metal oxide/silica aerogels. Micropor Mesopor Mater 75(1-2): 143-147.

3. Klabunde KJ, Stark J, Koper O, Mohs C, Park DG, etal. (1996) Nanocrystals as stoichiometric reagents with unique surface chemistry. J Phys Chem 100:12142-12153.

4. Richards R, LiW F, Decker S, Davidson C, Koper O, et al. (2000) Consolidation of metal oxide Nanocrystals. Reactive pellets with controllable pore structure that represent a new family of porous, inorganic materials. J Am Chem Soc 122(20): 4921-4925.

5. Wagner GW, Procell LR, Oconnor RJ, Munavalli S, Carnes CL, et al. (2001) Reactions of VX, GB, GD, and HD with nanosize $\mathrm{Al}_{2} \mathrm{O}_{3}$. Formation of aluminophosphonates. J Am Chem Soc 123(8): 1636-1644.

6. Mishakov IV, Zaikovskii VI, Heroux DS, Bedilo AF, Chesnokov VV, et al. (2005) $\mathrm{CF}_{2} \mathrm{Cl}_{2}$ decomposition over nanocrystalline MgO: Evidence for long induction periods. J Phys Chem B 109(15): 6982-6989.

7. Bedilo AF, Shuvarakova EI, Volodin AM, Ilyina EV, Mishakov IV, VedyaginAA, et al. (2014) Effect of modification with vanadium or carbon on destructive sorption of halocarbons over nanocrystalline MgO: The role of active sites in initiation of the solid-state reaction. J Phys Chem C 118(25): 13715-13725.

8. Hayashi K, Matsuishi S, Kamiya T, Hirano M, Hosono H, et al. (2002) Light-induced conversion of an insulating refractory oxide into a persistent electronic conductor. Nature 419: 462-465.

9. Kim SW, Toda Y, Hayashi K, Hirano M, Hosono H, et al. (2006) Synthesis of a room temperature stable $12 \mathrm{CaO} .7 \mathrm{Al}_{2} \mathrm{O}_{3}$ electride from the melt and its application as an electron field emitter. Chem Mater 18(7): 19381944.

10. Kitano M, Inoue Y, Yamazaki Y, Hayashi F, Kanbara S, et al. (2012) Ammonia synthesis using a stable electrode as an electron donor and reversible hydrogen store. Nature Chem 4: 934-940.

11. Bedilo AF, Sigel MJ, Koper OB, Melgunov MS, Klabunde KJ (2002) Synthesis of carbon-coated MgO nanoparticles. J Mater Chem 12: 35993604. 


\section{Juniper Online Journal Material Science}

12. Heroux DS, Volodin AM, Zaikovskii VI, Chesnokov VV, Bedilo AF, et al. (2004) ESR and HRTEM study of carbon-coated nanocrystalline MgO. J Phys Chem B 108(10): 3140-3144.

13. Volodin AM, Bedilo AF, Mishakov IV, Zaikovskii VI, Vedyagin AA, et al (2014) Carbon nanoreactor for the synthesis of nanocrystalline hightemperature oxide materials. Nanotechnol Russ 9(11-12): 700-706.
14. Volodin AM, Bedilo AF, Stoyanovskii VO, Zaikovskii VI, Kenzhin RM, et al. (2017) Nanocrystalline carbon coated alumina with enhanced phase stability at high temperatures. RSC Adv 7: 54852-54860.

15. Ferrari AC, Robertson J (2000) Interpretation of Raman spectra of disordered and amorphous carbon. Phys Rev B 61: 14095-14107.

\section{Your next submission with Juniper Publishers} will reach you the below assets

- Quality Editorial service

- Swift Peer Review

- Reprints availability

- E-prints Service

- Manuscript Podcast for convenient understanding

- Global attainment for your research

- Manuscript accessibility in different formats ( Pdf, E-pub, Full Text, Audio)

- Unceasing customer service

Track the below URL for one-step submission https://juniperpublishers.com/online-submission.php 